\title{
First Report Confirming the Occurrence of Jumping Halfbeak Hemiramphus archipelagicus Collette and Parin 1978 (Beloniformes: Hemiramphidae) from the Western Bay of Bengal
}

\author{
Anwesha Behera $^{1}$ - Subal Kumar Roul ${ }^{2}$ - A. Pavan Kumar ${ }^{1} \cdot$ Shashi Bhushan $^{1} \cdot$ Shardul S. Gangan $^{1} \cdot$ A. K. Jaiswar ${ }^{1}$ (D)
}

Received: 3 August 2019 / Revised: 31 October 2019

(C) Springer Nature Switzerland AG 2019

\begin{abstract}
The Jumping halfbeak, Hemiramphus archipelagicus Collette and Parin 1978, has been previously reported from the west coast of India (Arabian Sea). During a taxonomic study on Hemiramphidae, eight specimens of $H$. archipelagicus, collected from the coastal water of Odisha, east coast of India, were examined. The species is characterized by 13-14 dorsal-fin rays, 9-12 anal-fin rays, 11-12 pectoral-fin rays, 6 pelvic-fin rays, 25-28 gillrakers on first gill arch and 36-41 pre-dorsal scales, body width less than the depth (62.1-62.3\% in body depth), pectoral-fin short (17.2-18.4\% in SL) not reaching anterior margin of nasal pit when folded forward, dorsal fin without well-developed anterior lobe and absence of vertical bars on the sides of body. This is the first report confirming the occurrence of $H$. archipelagicus from the east coast of India (western Bay of Bengal) suggesting that this species is widely distributed throughout the Indian coast.
\end{abstract}

Keywords Hemiramphidae $\cdot$ Jumping halfbeak $\cdot$ Hemiramphus archipelagicus $\cdot$ East coast $\cdot$ India

\section{Introduction}

The fishes of family Hemiramphidae is commonly known as halfbeaks as the lower jaw is long like a beak, mostly marine except for few freshwater members of the genus, Hyporhamphus. They are distributed in the coastal continent of Atlantic, Indian and Pacific Oceans. Globally, the family comprises of 67 valid species in eight genera (Nelson et al. 2016). Among them, 15 species in five genera have been recorded to date from Indian waters. About eleven species in genus Hemiramphus has been described worldwide, including three species: Hemiramphus archipelagicus, $H$. far and H. lutkei from Indian waters (Froese and Pauly 2019). Studies on taxonomy of Indian hemiramphids are limited to several checklists/reports of regional importance and these studies portrayed the information only about their occurrence/ distribution without any detailed taxonomic information

A. K. Jaiswar

akjaiswar@cife.edu.in

1 ICAR-Central Institute of Fisheries Education, Mumbai, Maharashtra 400 061, India

2 Puri Field Centre of ICAR-Central Marine Fisheries Research Institute, Puri, Odisha 752 002, India or colour photographs (Barman et al. 2000; Barman et al. 2004, 2007, 2011, 2012, 2013; Rajan et al. 2013; Bijukumar and Raghavan 2015; Kar et al. 2017). Due to the similarity and overlapping of their morphological traits, the catch and occurrence of species are misreported/unreported. Therefore, the present study was conducted for a detailed taxonomic investigation of hemirampids from the Indian waters from 2018 to 2019. During our regular collection, $H$. archipelagicus was recorded from both the coasts of India. The earlier study reported the species only from the west coast of India (Collette 1984; Varghese 2005; Barman et al. 2012, 2013). Hence the specimens herein described as the first report confirming the distribution of $H$. archipelagicus from the east coast of India (western Bay of Bengal) based on morpho-meristic characteristics (Fig. 1). The species is distributed in the Indo-Pacific: Oman, Iran, Pakistan and west coast of India and Sri Lanka in the western part of Indian Ocean; east coast of India (present study) in the eastern part of Indian Ocean (Bay of Bengal); Vietnam and Taiwan in the South China Sea; Gulf of Thailand, Malaysia, Indonesia, Singapore, Philippines and Brunei Darsm in the Central Pacific; Cook Islands, Papua New Guinea, Samoa and Tonga in the South Pacific (Collette and Parin 1978; Collette 1984, 1999; Hata et al. 2018; Froese and Pauly 2019). 
Fig. 1 Map showing the distribution of Hemiramphus archipelagicus in the Indian Ocean. The red circles indicate the previous records and yellow circles indicate the present records

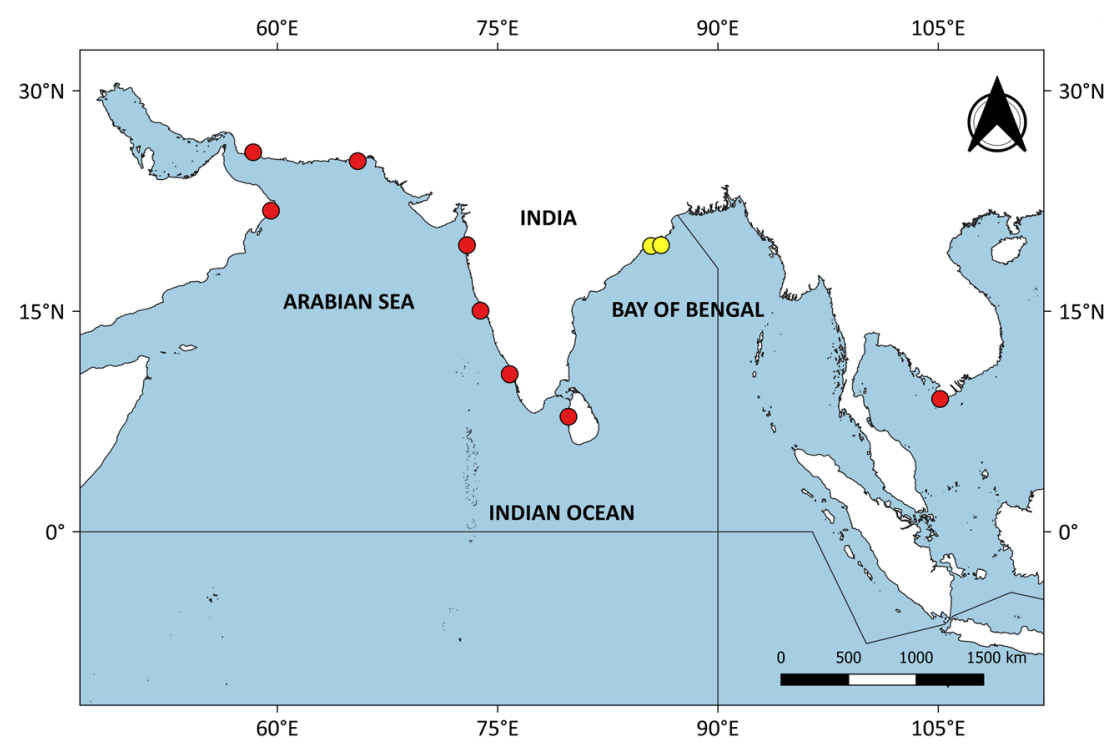

\section{Materials and Methods}

In the present study, specimens of hemiramphids were collected from New Ferry Wharf Fishing Harbour $\left(18^{0} 54^{\prime} \mathrm{N}, 72^{0} 49^{\prime} \mathrm{E}\right)$, Maharashtra; Chetty Fishing Harbour $\left(9^{0} 37^{\prime} 25.4814^{\prime \prime} \mathrm{N}, 76^{0} 17^{\prime} 44.7246^{\prime \prime} \mathrm{E}\right)$, Kerala; Tharuvaikulam landing centre $\left(08.17^{\circ} \mathrm{N}, 078.89^{\circ} \mathrm{E}\right)$, Tamil Nadu; Puri North landing centre $\left(19^{\circ} 47^{\prime} 43.062^{\prime \prime}\right.$ $\left.\mathrm{N}, 85^{\circ} 49^{\prime} 38.5788^{\prime \prime} \mathrm{E}\right)$ and Astaranga Fishing Harbour $\left(19^{0} 58^{\prime} 25.9284^{\prime \prime} \mathrm{N}, 86^{0} 20^{\prime} 21.7464^{\prime \prime} \mathrm{E}\right)$, Odisha, along the Indian coast, during 2018 to 2019. The specimens collected from Maharashtra, were caught mainly using drift gill net (mesh size 40-60 mm); specimens from Kerala by traditional ring seines (mesh size $8-10 \mathrm{~mm}$ ) locally known as 'choodavala'; specimens from Tamil Nadu by drift gill net (mesh size $40 \mathrm{~mm}$ ), locally known as 'mural valai'; and specimens from Odisha caught by drift gill net (mesh size $32-52 \mathrm{~mm}$ ). Fresh specimens were brought to the laboratory in iced condition, photographed in fresh condition and identified based on the key given by Collette (1984) and Collette (1999). Morphometric measurements and meristic counts were recorded according to Hubbs and Lagler (2004). The morphometric characters, with $0.1 \mathrm{~mm}$ accuracy and total body weight with $1 \mathrm{~g}$ accuracy, were measured using a digital Vernier calliper and electronic weighing balance, respectively. The selected morphometric measurements were expressed in percentage of standard length (SL) and head length (HL). The specimens were dissected in order to record the sex. One specimen of each species was fixed in $10 \%$ formalin and stored at Fisheries Resource management laboratory, ICARCentral Institute Fisheries Education (CIFE), Mumbai, India, for future reference.

\section{Material Examined}

Hemiramphus archipelagicus: 8 ex: 195.7-199.9 mm SL, 74.4-148.0 g TW, collected from Puri North landing center and Astaranga Fishing Harbour, Puri, Odisha, India, collector Subal Kumar Roul, 19 August, 24 October, 4 November 2018; 16 ex: 155.4-352.6 mm SL, 11-193 g TW, collected from Chetty Fishing Harbour, Kerala and New Ferry Wharf landing center, Maharashtra, India, collector Anwesha Behera, Jeevan T M, 9 October, 12 December 2018.

Hemiramphus lutkei: 26 ex: 232.2-336.7 SL, 77-100 g TW, collected from Tharuvaikulam landing center, Tamil Nadu, New Ferry Wharf fishing harbor, Maharashtra, India, collector Anwesha Behera, Shardul. S. Gangan, 3 October, 15 October, 12 December 2018.

Hemiramphus far: 26 ex: 132.1-295.6 mm SL, 25-103 g TW, collected from Tharuvaikulam landing center, Tamil Nadu, Chambakkara fish market, Kerala, collector Anwesha Behera, 3 October, 10 December 2018.

\section{Results}

Hemiramphus archipelagicus Collette and Parin 1978

Jumping halfbeak (Fig. 2a, Table 1).

\section{Morphological Features}

\section{Morphometric Characteristics}

Dorsal-fin rays 13-14; anal-fin rays 9-12; pectoral-fin rays 11-12; pelvic-fin rays 6; gillrakers on first gill arch 25-28, pre-dorsal scales 36-41. 

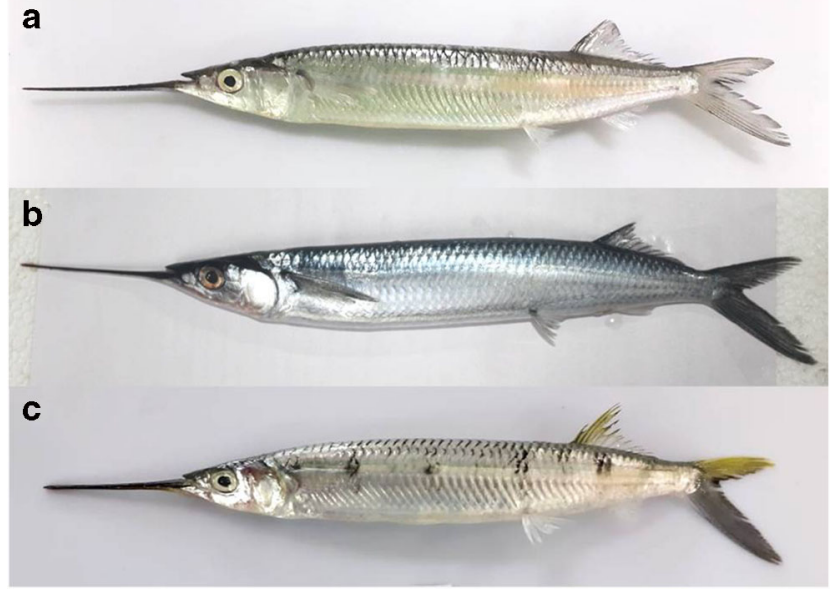

Fig. 2 Fresh specimens of three species of the genus Hemiramphus. a Hemiramphus archipelagicus, $195.7 \mathrm{~mm}$ SL, Puri North Landing Center, Odisha, India; b) Hemiramphus lutkei, $210 \mathrm{~mm}$ SL, Tharuvaikulam Landing Center, Tamil Nadu, India; C) Hemiramphus far, 238 mm SL, Astaranga Fishing Harbour, Odisha, India

Body elongated and slightly cylindrical. Dorsal profile rising slowly from the tip of snout to above the pectoral-fin insertion and thereafter parallel to the body axis to dorsal fin origin. Compared to the dorsal profile, ventral profile slightly arched from below the tip of the snout to the base of the caudal fin. Body width less than the body depth (62.1-62.3\% in body depth). Lower jaw greatly prolonged into a beak-like structure (148.2-248.9\% in HL), whereas upper jaw short (24.2-25.8\% in HL), triangular in dorsal view and scale less. Pre-orbital ridge absent and nostrils with an oval-shaped nasal fossa. Both the jaw having dense, minute and conical teeth whereas tongue and vomer toothless. Body scales large, thin, cycloid and deciduous. Pectoral-fin short (17.2-18.4\% in SL), not reaching past nasal pit when folded forward (length less than the distance between its origin to anterior margin of nasal fossa). Pelvic-fin also short and posterior to mid-body length. Dorsal and anal fins positioned posteriorly. Dorsal-fin lacks well developed anterior lobe. Caudal-fin deeply forked.

\section{Colour of a Fresh Specimen}

The lateral surface of body silvery white with a silvery lateral stripe, widening posteriorly and dark bluish above without any vertical bars on sides. Lower jaw black with a reddish fleshy anterior tip. Pectoral, pelvic, and anal fins translucent, with melanophores on fin rays. Dorsal fin translucent and outer margin blackish colour. Caudal fin pale green and margin of both upper and lower lobe of caudal blackish.

\section{Colour of Formalin Preserved Specimen}

Silvery white coloration of the lateral surface of the body and the reddish fleshy tip of lower jaw became straw colour. Dorsal surface of body and head become pale grey/black.
The lateral stripe turned into a prominent black stripe. Melanophores on pectoral, pelvic, and anal fins are clearly visible. The dorsal fin and caudal fins became blackish/ greyish colour.

\section{Discussion}

The fishes were identified as Hemiramphus archipelagicus (Fig. 2a) based on based on morpho-meristic characters (Table 1). Most of the meristic counts and proportional morphometric characters of the present specimens were concurrent with the earlier references except for few. Collette and Parin (1978) and Collette (1999) recorded lower proportions for pectoral fin length ( $16.6 \%$ of SL), body width in depth (50.0-55.6\%), while higher number for gillrakers on first gill arch (29), lower pre-dorsal scales (36), based on examination of specimens ranged from 147 to $220 \mathrm{~mm} \mathrm{SL}$. This relative difference in morphological characteristics may be related to the size range of the specimens examined. Three species of Hemiramphus namely $H$. archipelagicus, $H$. lutkei and $H$. far are found along the Indian coast (Collette 1984, 1999; Varghese 2005; Froese and Pauly 2019) (Fig. 2). Jones and Kumaran (1980), Manna and Goswami (1985), Sethi et al. (2013), Rajan et al. (2013), Joshi et al. (2016), Kar et al. (2017) and Kayalvizhi et al. (2018) reported one more species namely H. marginatus from Indian waters but their distribution is mostly restricted to the Red Sea and the Persian Gulf in the western Indian Ocean (Carpenter et al. 1997). Such reports from Indian waters are questionable which might have been misidentified with morphologically similar species occurring in the area. Among the above listed three species, $H$. archipelagicus can be easily distinguished from $H$. far where the latter possesses, mostly in adults, 4 to 6 short dark vertical bars on the sides of the body. Hemiramphus archipelagicus can be distinguished from H. lutkei by its relatively a shorter pectoral fin (14.7-19.2\% $\mathrm{SL}$ ) and not reaching anterior margin of nasal pit when folded forwards whereas the latter possesses longer pectoral fin (18.5-22.2\% SL), reaching beyond the anterior margin of nasal pit when folded forward; the former possesses fewer gillrakers on the first gill arch (25-32) vs. 33-46 (usually 36 to 41) in H. lutkei, as well as fewer pre-dorsal scales (29-41, and usually fewer than 37 vs. 35-43, and usually more than 37 in $H$. lutkei); dorsal fin with well-developed anterior lobe in H. far and absent in H. archipelagicus and H. lutkei (Collette and Parin 1978; Collette and Su 1986; Collette 1999; Hata et al. 2018; present study).

The distributional range of $H$. archipelagicus was previously thought to be restricted to the west coast of India (Collette 1984; Varghese 2005; Barman et al. 2012, 2013) as this species had not been reported from the entire east coast of India (Barman et al. 2004, 2007, 2011; Kar et al. 2017) and 
Table 1 Meristic and morphometric parameters of Hemiramphus archipelagicus. Body proportions are expressed as a percentage of standard length and head length

\begin{tabular}{|c|c|c|}
\hline \multirow{3}{*}{$\begin{array}{l}\text { Species } \\
\text { Authors } \\
\text { Locality }\end{array}$} & \multicolumn{2}{|l|}{ H. archipelagicus } \\
\hline & Present Specimens & Hata et al. (2018) \\
\hline & Odisha, India & Kaohsiung, Taiwan \\
\hline No. of specimens examined & 8 & 1 \\
\hline Standard Length (SL mm) & $195.7-199.9$ & 230.8 \\
\hline \multicolumn{3}{|l|}{ Morphometric characters } \\
\hline \multicolumn{3}{|l|}{ In $\%$ of $\mathrm{HL}$} \\
\hline Head depth & $14.1-14.5$ & - \\
\hline Eye diameter & $23.4-24.1$ & - \\
\hline Snout length & $24.6-26.1$ & - \\
\hline Pre-orbital length & $8.0-8.3$ & - \\
\hline Post-orbital & $9.6-10.6$ & - \\
\hline Upper jaw length & $24.2-25.8$ & - \\
\hline Lower jaw length & $148.2-248.9$ & - \\
\hline Inter-orbital width & $24.3-25.9$ & - \\
\hline Inter-nasal width & $16.0-17.7$ & - \\
\hline Distance between nasal pit to pectoral fin origin & $70.4-75.9$ & - \\
\hline \multicolumn{3}{|l|}{ In $\%$ of SL } \\
\hline Head length & $22.8-23.5$ & 21.7 \\
\hline Pre-dorsal length & $75.7-76.4$ & - \\
\hline Pre-anal length & $81.5-82.0$ & - \\
\hline Pre-pelvic length & $67.9-68.4$ & - \\
\hline Pre-pectoral length & $23.6-23.7$ & - \\
\hline Dorsal fin length & $12.2-12.3$ & - \\
\hline Dorsal base length & $16.0-17.8$ & 15.9 \\
\hline Anal fin length & $8.6-8.9$ & - \\
\hline Anal base length & $9.8-10.1$ & 10.3 \\
\hline Pectoral fin length & $17.2-18.4$ & 16.6 \\
\hline Pelvic fin length & $7.9-8.3$ & - \\
\hline Body depth & $15.8-16.4$ & 16.1 \\
\hline Body width & $9.8-10.2$ & 9.6 \\
\hline Depth at dorsal origin & $14.0-14.5$ & - \\
\hline Caudal peduncle length & $7.4-7.5$ & - \\
\hline Caudal peduncle depth & $6.4-6.7$ & - \\
\hline \multicolumn{3}{|l|}{ Meristic counts } \\
\hline Dorsal fin rays & $13-14$ & 14 \\
\hline Analfin rays & $9-12$ & 12 \\
\hline Pectoral fin rays & $11-12$ & 12 \\
\hline Pelvic fin rays & 6 & 6 \\
\hline Gillrakers (total) & $25-28$ & 29 \\
\hline Pre-dorsal scales & $36-41$ & 36 \\
\hline
\end{tabular}

other parts in the Bay of Bengal (Fig. 1). However, recently Kayalvizhi et al. (2018) reported H. archipelagicus from Tamil Nadu coast in the "Checklist of beloniform fishes of coastal waters of Thoothukudi, southeast coast of India" without any detailed taxonomic notes and colour photographs which might have misidentified with similar and sympatric species of the genus Hemiramphus occurring in the area. In the present study, specimens of Hemiramphus were also collected from the Thoothukudi coast, Tamil Nadu and all the specimens were identified and confirmed either $H$. far or H. lutkei. Similarly, H. lutkei was reported from West Bengal (Yennawar et al. 2017), Andhra Pradesh (Barman et al. 2004), Tamil Nadu (Barman et al. 2011), Sri Lanka (Collette 1984), and Andaman and Nicobar Islands (Rajan 
et al. 2013) in the Bay of Bengal whereas $H$. far was reported from the entire east coast of India (Yennawar et al. 2017; Barman et al. 2004, 2007, 2011), Sri Lanka (Collette 1984), and Andaman and Nicobar Islands (Rajan et al. 2013). The members of the genus Hemiramphus enjoy a wide distribution both in east and west coast of India. However, prior to the discovery of $H$. archipelagicus in east coast (western Bay of Bengal) during the present study, the species was only known from the west coast of India (eastern Arabian Sea). Since several coastal areas in the east coast of India provides a suitable habitat for this genus as indicated by the occurrence of its congeneric species. The discontinuity in the distribution of $H$. archipelagicus along Indian coast might result from misreporting or unreporting. This may be due to the lack of dedicated/regular taxonomic investigation/survey along the Indian coast. Therefore, the specimen described herein represents the first record confirming the occurrence of $H$. archipelagicus from the east coast of India (Bay of Bengal).

Acknowledgments The authors are highly grateful to and Dr. Gopal Krishna, Director, ICAR-CIFE, Mumbai for providing all necessary facilities and constant support during the entire study period.

\section{Compliance with Ethical Standards}

Conflict of Interest The authors declare that they have no conflict of interest.

Ethical Approval This article does not contain any experimental studies with animals performed by any of the authors.

\section{References}

Barman RP, Kar S, Mukherjee P (2004) Marine and estuarine fish. In Fauna of Andhra Pradesh, State Fauna Series. Zool Surv India 5(2):97-311

Barman RP, Mishra SS, Kar S, Mukherjee P, Saren SC (2007) Marine and estuarine fish fauna of Orissa. Rec Zool Surv India 260:1-186

Barman RP, Mishra SS, Kar S, Mukherjee P, Saren SC (2011) Marine and estuarine fish. In Fauna of Tamil Nadu, State Fauna Series. Zool Surv India 17(2):293-418

Barman RP, Mishra SS, Kar S, Mukherjee P, Saren SC (2012) Marine and estuarine fish. In Fauna of Maharashtra, State Fauna Series. Zool Surv India 20(1):369-480

Barman RP, Mishra SS, Kar S, Saren SC (2013) Marine and estuarine fish. In Fauna of Karnataka, state Fauna series. Zool Surv India 21: 277-387

Barman RP, Mukherjee P, Kar S (2000) Marine and estuarine fish. In Fauna of Gujarat, State Fauna Series. Zool Surv India 8(1):311-411

Bijukumar A, Raghavan R (2015) A checklist of fishes of Kerala, India. J Threat Taxa 7(13):8036-8080. https://doi.org/10.11609/jott.2004.7. 13.8036- 8080
Carpenter KE, Krupp F, Jones DA, Zajonz U (1997) FAO species identification field guide for fishery purposes. Living marine resources of Kuwait, eastern Saudi Arabia, Bahrain, Qatar, and the United Arab Emirates. FAO, Rome. 293 p

Collette BB (1984) Hemiramphidae. In W. Fischer and G. Bianchi (eds.) FAO species identification sheets for fishery purposes. Western Indian Ocean (fishing area 51), volume 2. FAO, Rome

Collette BB (1999) Hemiramphidae. Halfbeaks. In: Carpenter KE \& Niem V (Eds.), FAO species identification guide for fishery purposes. Vol. 4. Bony fishes, part 2 (Mugilidae to Carangidae). Rome, FAO. pp. 2180-2196

Collette BB, Parin NV (1978) Five new species of halfbeaks (Hemiramphidae) from the indo-West Pacific. Proc Biol Soc Wash 91(3):731-747

Collette BB, Su J-X (1986) The halfbeaks (Pisces, Beloniformes, Hemiramphidae) of the Far East. Proc Acad Natl Sci Phila 138: 250-302

Froese R, Pauly D (eds) (2019) FishBase 2019, version (July 2019). World Wide Web electronic publication Retrieved from http:// www.fishbase.org

Hubbs CL, Lagler KL (2004) Fishes of the Great lake Regions (Revised Ed.), University of Michigan Regional. 332p.

Hata H, Koeda K, Ho HC, Motomura H (2018) First record of Hemiramphus archipelagicus (Beloniformes: Hemiramphidae) from Taiwan. Platax 15:65-71

Jones S, Kumaran M (1980). Fishes of the Laccadive archipelago. The nature conservation and aquatic sciences service, Santinivas, Nanthancode, Trivandrum-695003, Kerala, India. 759 pp.

Joshi KK, Sreeram MP, Zacharia PU, Abdussamad EM, Varghese M, Habeeb Mohammed OMMJ, Jayabalan K, Kanthan KP, Kannan K, Sreekumar KM, George G (2016) Check list of fishes of the Gulf of Mannar ecosystem, Tamil Nadu, India. J Mar Biol Assoc India 58(1):34-54. https://doi.org/10.6024/jmbai.2016.58.1.189505

Kar A, Raut SK, Bhattacharya M, Patra S, Das BK, Patra BC (2017) Marine fishes of West Bengal coast, India: diversity and conservation preclusion. Reg Stud Mar Sci 16:56-66. https://doi.org/10. 1016/j.rsma.2017.08.009

Kayalvizhi E, Jayakumar N, Jawahar P, Srinivasan A (2018) Checklist of beloniform fishes of coastal waters of Thoothukudi, southeast coast of India. J Entomol Zool Stud 6(6):306-309

Manna B, Goswami BCB (1985) A check-list of marine and estuarine fishes of Digha, West Bengal, India. Mahasagar 18(4):489-499

Nelson JS, Grande TC, Wilson MV (2016). Fishes of the world (5 $5^{\text {th }}$ ed.). John Wiley and Sons, Hoboken, New Jersey.707 pp

Rajan PT, Sreeraj CR, Immanuel T (2013) Fishes of Andaman and Nicobar Islands: a checklist. J Andaman Sci Assoc 18(1):47-87

Sethi SN, Jithendran KP, Kannappan S (2013) Co-infection of yellow tip halfbeak fish (Hemiramphus marginatus) with isopod and copepod parasites from the Coromandal coast, India. Fish Technol 50:357360

Varghese AS (2005) Systematic and biology of fishes of the family Hemiramphidae of Cochin coast. Ph.D. Thesis. Cochin University of Science and Technology, Cochin, Kerala, India. 360 pp

Yennawar P, Mohapatra A, Tudu PC (2017) An account of Ichthyofauna of Digha coast, West Bengal. Rec Zool Surv India 117(1):4-21

Publisher's Note Springer Nature remains neutral with regard to jurisdictional claims in published maps and institutional affiliations. 